\title{
NATIONAL COMMITTEE OF REPRESENTATIVES
}

\section{SEVENTH MEETING, HELD ON SATURDAY 3rd MAY 1980 IN JOHANNESBURG}

\begin{abstract}
After apologies had been noted, the members present were identified because several new members or representatives were present. Tribute was paid to the memory of Lilian Erasmus from Eastern Province, who had been a faithful member of the Society and regular attendant at previous meetings.
\end{abstract}

\section{NATIONAL EXECUTIVE COMMITTEE REPORT} (Read by Mrs. A. Matthias, Chairman)

The report covered the period from November 1979 to May 1980. Four meetings had been held. The resigations of the following were noted with regret: Miss Hazel Baines (Treasurer) returned to England in February; Miss Leone Pretorius (Chairman of the Afrikaans Translation Committee) has moved to Stutterheim; Mrs. V. Fogarty, who had been co-opted as Assistant Treasurer, could not continue in this capacity. Miss Elizabeth Botting, who had agreed to act as temporary Treasurer.

A sub-committee consisting of Miss Irwin-Carruthers, Miss Runnalls and Miss Winter has been convened to draw up a memorandum on the amendment of Rule 21 of the Professional Board so as to bring it into line with Ethical Rule J45(a) as amended at the previous Council Meeting. Rule 21 specifies the acts or omissions in respect of which disciplinary steps may be taken by the Professional Board of Physiotherapy and S.A. Medical and Dental Council.

Industrial Physiotherapy was mentioned as a branch with great potential in this country. The manner in which this growth is handled will influence our whole profession.

The procedure for organizing postgraduate courses run jointly by N.E.C. and Branches was clarified, the major organizer (N.E.C. or Branch) being identified. Branches will be responsible for local arrangements where N.E.C. arranges a course, and should be consulted as regards speaker, dates, etc. Guidelines for jes and honoraria had been drawn up; acceptance And cancellation dates must be stated by the organizers. Branches are to donate $20 \%$ of profits to the P.P.K. Fund when organizing a course, and N.E.C. is to donate $20 \%$ to the Branch involved in any course organized by N.E.C. Recently N.E.C. had been involved in the following courses:

Dr. Ruth Purtilo, an expert in ethics and rehabilitation led workshops on these topics in Southern Transvaal and Western Province. She also addressed these Branches as well as students from training centres in these areas.

Misses P. Blake and M. A. van der Velde ran a most successful course on normal motor development and a neurodevelopmental therapy approach to facilitation of movement. Attendances at these reflected the vitality and work-orientation of physiotherapists.

The 9th International Congress of the World Confederation for Physical Therapy (W.C.P.T.) will be held in Stockholm in May 1982. The theme "MAN IN ACTION" is deliberately non-specific in order to evoke a maximal general response. Information for speakers is available from Branches, Special Groups. Training Centres, or chairmen of sub-committees. All physiotherapists are encouraged to submit papers in order to reflect the work done by physiotherapists in this country.

An African Physiotherapy Association was founded at the first Pan-African Congress held in Nigeria. The Society has applied for membership.

A regional seminar on biofeedback and electromyography will be held in Geneva from 1-4 October 1980 under the guidance of Prof. J. B. Basmajian.

Mrs. Matthias, Miss E. Smith and Mrs. B. van der Watt had an interview with authorities as regards salaries and conditions of service of physiotherapists in hospital services. According to the Public Service Commission, physiotherapy salary increases ranged from $7-30 \%$, more attention being given to parity of black and white salaries. The Society has been invited to submit suggestions for further changes. Motivation, based on analysis of physiotherapy services needed, is required to improve staff establishment at hospitals. Mrs. Matthias suggested that we heed what Prof. le Roux of Wentworth Hospital, Durban, says in his open letter to physiotherapists. Physiotherapists in hospital service can no longer claim to be victims of "the system". Authorities are favourably disposed to improving physiotherapy services, but the correct procedures in health administration are essential. The National Hospital Group has a challenging and exciting task ahead, in supporting and assisting hospital staff to achieve satisfactory conditions and in publicizing the stimulation, satisfaction and long-term advantages to be found in hospital service.

\section{REPORT FROM THE PROFESSIONAL BOARD FOR}

PHYSIOTHERAPY (Read by Mrs. K. M. Levy, President of the S.A.S.P. and Chairman of the Professional Board for Physiotherapy.)

The 16th meeting of the Professional Board for Physiotherapy was held in February 1980 , and reported to the S.A. Medical and Dental Council meeting held in Pretoria on 15 April 1980.

The number of registered physiotherapists at the end of December 1979 was 1772 . During 1979,182 names were added but 93 were erased. On 1 February 1980 , 144 registered physiotherapists had failed to pay their annual fees and it was agreed to erase their names at 31 March if fees were still unpaid.

It has been agreed that the physiotherapy degree conferred by Durban-Westeville will in future be known as a Bachelor in Physiotherapy. This has been added to the list of registrable qualifications.

Additional qualifications registrable by physiotherapists were discussed and the following agreed to: Continued recognition will be given to the Diploma in Teaching Physiotherapy and Diploma in Intensive Care Physitherapy of the University of Cape Town; Diploma in Physiotherapy Education and the Degree of Master of Science in Physiotherapy of the University of the Witwatersrand and the Degree of Master of Science of the University of Stellenbosch. The following to be added to the list: The Degree of Master of Physiotherapy of the University of Durban-Westville; the Tertiary Education Diploma in Physiotherapy of the University of the Orange Free state; the Diploma in Advanced Physiotherapy of the University of the Wit- 
watersrand and the Degree of Master of Science (Physiotherapy) of the University of Cape Town.

A Tertiary Education Diploma is offered by the University of South Africa. The Medical Council has decided that provided a person holds a primary qualification in a practical profession and the Council is satisfied that the course content justifies its recognition, it can be accepted as an additional qualification. Accordingly, the Professional Board has agreed that, given the assurance that a physiotherapist will be responsible for the evaluation and assessment of the examinations for the proposed Diplomas as regards physiotherapy, the Diploma will be recognized as an additional qualification.

The Board suggested that the Society approach suitable training institutions prepared to offer courses such as Diploma in Neurodevelopment therapy for physiotherapists and undertake the examinations. The institutions could then apply for these courses to be recognized as additional registrable qualifications.

The Executive Committees of the Occupational and Physiotherapy Boards have met since the last meeting of the S.A. Medical and Dental Council, and agreed that the words "recreational activities" be used in conjunction with physiotherapy and "recreational therapy" with occupational therapy where possible. The Board requested the Council to forward these proposed amendments to the Minister, and the Council agreed to these suggestions.

The memorandum on the scope for masseurs submitted by the Society has been forwarded to the Supplementary Health Services Committee for comment. The Society has also been requested to draw up a document on the scope of remedial gymnasts and this task will have to be allotted.

It was agreed that a Tariff Committee will be appointed from a panel of physiotherapists which has been submitted by the Board, when the newly elected Council is constituted in July.

Council agreed that physiotherapists may accept payment for professional services by means of a credit card, subject to certain conditions. These conditions will be sent to the Private Practitioners' Association for circulation to their members.

We await the final outcome of the amendments suggested by the Minister to the Medical, Dental and Supplementary Health Service Professions Act. The Bill has reached the Senate stage, and as far as can be ascertained, the registration clauses have been passed, which will mean prescription of the whole country.

The Board held its first enquiry into the conduct of a registered physiotherapist charged with improper conduct; as a result of the enquiry the physiotherapist concerned was reprimanded and cautioned.

\section{Additional Matters Arising}

There was a long discussion on the suggested establishment of health teams by private medical practitioners. A report was tabled on behalf of the Private Practitioners' Association. From the discussion it emerged that physiotherapists were not in favour of being employed by private medical practitioners, but it was felt that the principle of the establishment of health teams should be strongly supported. Most represenatives favoured a form of partnership and suggested that a total health service should include medical specialists, dentists, etc. There was obvious concern for the lack of services available to the black community and it was felt that this should be planned for. Suggestions on the ways of establishing such health teams should be submitted to N.E.C
FINANCIAL REPORT (Read by Miss E. Botting, Acting General Treasurer)

Miss Botting stated that it has become increasingly obvious that the National Executive Committee should appoint a Deputy General Treasurer so that there will be two members with intimate knowledge of the Society's financial affairs. Thus there always will be someone who can take over the financial affairs without any break in continuity. The Finance Committee has met at regular intervals since the last N.C.R. meeting and a detailed breakdown of the assets of the S.A.S.P. was presented.

In discussion it was noted that the investments from the P.P.K. Fund (Propagation of Professional Knowledge Fund) had been used towards one grant and two loans during the financial year under discussion.

EDITORIAL BOARD REPORT (Read by Mrs. J. A. C. Gilder, Journal Editor)

Members were urged to contact their Branch Secretary when notifying change of address. Volumes I, II and III of the Journal are still missing and an appeal is made to members for these in order to complete the journal binding. To increase advertising in the Journal it was felt that a permanent representative in the Witwatersrand area is required in order to maintain personal contact with potential advertisers.

\section{REPORT FROM APPOINTMENTS INFORMATION SECRETARY (Read by Miss P. Blake)}

Since the last meeting there have been few enquiries, the majority being from the United Kingdom.

\section{REPORTS AND MATTERS ARISING FROM THE SUB-COMMITTEES}

Activations Committee (Read by Mrs. L. Thompson)

The Committee is to concentrate on public relations this year, particularly on relations between individual physiotherapists, Branches, Groups, and students.

Since the last meeting a reference guide to health care has been completed and forwarded to the Department of Health, the possibility of setting up slide/tape library has been investigated, memoranda. have been sent to branches and groups requesting information on activities, information on student involvement has been compiled, standards of physiotherapy are to be investigated, and a workshop for P.R.O.'s is being planned in conjunction with the Council to be held in 1981 .

In discussing this report it was also felt that the Activations Committee should publicize our position as regards salaries and conditions of service through the public media, as has been done by the teachers.

\section{Constitution Committee (Read by Miss Irwin-Carruthers)}

An addendum, setting out the amendments to the Constitution and By-Laws which had been passed at the 12th and 13th National Council Meetings, was tabled. It was agreed that this addendum be used for reference and that printing would be postponed until after the next National Council Meeting, in view of the increased cost. Special Interest Groups were requested to forward their revised constitutions to the Committee in order that they may be finalized at the next National Council Meeting. 


\section{Investigating Committee (Read by Miss Bowerbank)}

It has emerged that post-basic courses should be run under the auspices of a recognized educational authority in order to be considered for the registration of additional qualifications with the Professional Board. Physiotherapists with a diploma still have not been catered for, and the accreditation for clinical competence which is being considered in the U.S.A., will be investigated.

The results of a survey of caseloads in teaching hospitals were tabled. It was interesting to note that the mean attendances in this study (15,6 attendances per day) correspond very closely to those in a comprehensive study carried out by the Canadian Physiotherapy Association in 1978. This study recommended that the standard attendances per physiotherapist-day in a $500+$-bed teaching hospital be $13,0-16,0$. This investigation has implications in setting guidelines for maximal productivity, at the same time maintaining the quality of care. The study is to be extended to other hospitals including nonteaching hospitals.

\section{Registration Committee (Read by Mrs. Beenhakker)}

No full registrations had been recommended, but limited registration had been offered to one applicant from Sweden and two from Austria. It was agreed that the Professional Board be requested to consider the reduction of the initial period of limited registration to one year. Minimal standards of training acceptable for registration of physiotherapists have to be submitted to the Board by the Society. The driteria for registration of additional qualifications will also have to be revised in view of the acceptance of the Tertiary Education Diplo$\mathrm{ma}$ of UNISA as a registrable qualification. r

\section{REPORT AND MATTERS ARISING FROM BRANCHES}

\section{Border (Read by Mrs. E. Lombard)}

The Branch consists of 23 members and attendance at meetings has improved. Branch members were also involved with careers information.

Ten members of the Branch now live in Transkei and wish to know whether they should form their own independent branch affiliated to the S.A.S.P., or merely remain as members of the Border Branch. In discussion it was pointed out that constitutionally neither an independent nor an affiliated branch of the S.A.S.P. could be formed. It was suggested that this matter be referred to Sub-committee for investigation prior to the next National Council Meeting.

The Branch also expressed difficulty in meeting their contribution to the expenses of the N.C.R. However, it was clear that the Branch had misunderstood the financial bulletins and the General Treasurer would clarify the matter. fi..

\section{Eastern Province (Read by Mrs M. J. L. Butler)}

The activities of the Branch during the past 6 months were described. There were several interesting lectures and two post-registration courses were planned for later this year.

\section{Goldfields (Read by Miss Irwin-Carruthers)}

There was no representative and the Report had been drawn up by Mrs. Stonestreet. The membership is 27. Several interesting lectures, at which the attendance had been good, had been held. It was felt that there was an encouraging interest in Branch activities.

\section{Natal Coastal (Read by Mrs. J. Nankin)}

This Branch has 114 members. The National Parolympic Games were held in Durban and Branch members were very involved in the activities of the Games.

In November a very successful symposium on backache was attended by over 200 people. A panel consisting of an orthopaedic surgeon, a gynaecologist, an acupuncturist, a chiropractor and a physiotherapist discussed backache under the chairmanship of Prof. Sarkin, Dean of the Faculty of Medicine. In January Mr. Vythilingum gave a lecture on myocardial disease which was followed by a demonstration of cardiac rehabilitation by Ms. Higgins, Calvert, Kelly and Blackwood. In February Mr. Charles Liggins discussed the implications of research, a rheumatologist, gave an informal talk on the hand, Dr. McDonald-Scott, a rheumatologist, gave an informal talk on the hand. The Branch held a business meetin in April to discuss the Agenda for the N.C.R. This was followed by a lecture, illustrated with slides, on the value of chest physiotherapy in the child, given by $\mathrm{Mr}$. Gounden.

Mrs. de Villiers has been transferred to the Cape, Ms. P. Martins and A. Hutchinson have moved to the Transvaal, and Mrs. F. Jordaan has joined the Branch from the Northern Transval. New members who have joined the Branch are: Ms S. Mars, L. Schalit, R. Fisher-Jeffes, P. Leibrandt, R. Wagner, A. Smit, H. Forbes, F. Zieseniss, and R. Casely.

The Branch expressed sincere regret at the death of Margaret Warbrugh. Margaret worked as a physiotherapist for over 40 years. In 1969, after the death of her employer, Dr. Max Gitlin, a physical medicine specialist, she started her own practice which she continued to run until last year. Although she suffered from Hodgkin's disease for the last 16 years, she worked tirelessly and made a valuable contribution to the profession. She is sadly missed by colleagues and patients.

\section{Natal Midlands (Read by Mrs. P. Lief)}

There are 27 members in this Branch and it has been active, holding monthly meetings. Mrs. Horsley gave a lecture/demonstration on connective tissue massage, Dr. Higgs, a paediatrician, lectured on allergy clinics for children, Miss S. Blackwood gave a lecture on heated humidification, Mr. C. Liggins lectured on T.E.N.S., Mrs. Bennett gave a lecture/demonstration on child hemiplegia, Dr. Meiring gave a lecture on diabetes, Mrs. G. van Schaik gave a lecture/demonstration on the rehabilitation of adult hemiplegia, and Mrs. Tarr gave a lecture/demonstration on Miss Roodt's technique. Three members of the Branch also lectured to nonpractising nursing members.

The Branch asked whether a doctor could be their medical liaison officer instead of the Branch President. The meeting felt that constitutionally it would be better if Dr. P. Thompson were appointed Branch President, but certainly his service as medical liaison officer would be appreciated.

\section{Northem Cape (Read by Mrs. M. Klemp)}

The 22 members of this Branch travel long distances to attend meetings regularly. The Branch requested help in motivation for the creation of a post at a country hospital, and was advised to approach the Regional Medical Superintendent about this matter. It also 
wished to have information on the cost of training at the various Training Institutions at the beginnning of each academic year. A representative of the Lecturers' Group agreed to assist them in obtaining these costs at the beginning of each year.

\section{Northern Transvaal (Read by Mrs. Y. Cohen)}

This Branch now has 200 members, and attendance at meetings and social functions tend to be average. $A$ supper party at the end of the year was most successful. A cocktail party for the students was attended by Dr. Hugo, the Honorary President; Prof. Bam and Dr. Beighton, Vice-Presidents, as well as students from the Pretoria College and MEDUNSA Pat Bowerbank gave a very descriptive lecture on Societies in general and the S.A.S.P. in particular. Prizes were awarded to the students as follows: The best student throughout 3 years of study was Miss Mathothoma of MEDUNSA who was awarded a book voucher; the most promising final year student in clinical work in 1979 was Miss C. Pretorius of the Physiotherapy College, who was awarded a book prize.

The Executive Committee meets monthly with good attendance. The Committee now consists of 9 members; 11 were elected at the A.G.M. in October, 3 have since resigned, and 1 new member has been co-opted.

In February Professor Irsigler spoke to the Branch on chronic chest conditions and the use of a stethoscope. Mrs. Louise Hack gave a lecture on backache in pregnancy in March, and discussed her visit to the Back Education Unit in Toronto, and Dr Sperryn also addressed members on sport injuries-treatment and rehabilitation. Southern Transvaal Branch was thanked for the opportunity that members of Northern Transvaal Branch had to attend Dr Purtilo's symposium as well as the evening lecture given by her.

The Branch has been very busy organising the conference and 14th Council meeting which is to be held in Pretoria from 23-27 March 1981. A full programme will appear in the September issue of the Journal. Four committees, namely Academic, Finance, Publicity, and Entertainment, Transport and Accommodation, have been set up to deal with the organisation of the Congress and Council meeting. The C.S.I.R. Conference Centre will be the venue for the Congress and the Auditorium at the College will be the venue for the Council meeting. Thanks were expressed to Western Province Branch for the loan of their Conference file, which has helped the Branch a great deal, and thanks were also expressed to the N.E.C., Branches and Subgroups who have submitted ideas and suggestions.

\section{Suid-Oranje Vrystaat (Gelees deur Mev. Crous)}

Die ledetal van die Tak is 34 , maar tak-aktiwiteite het 'n stil tydperk beleef. In November 1979 is die Algemene Jaarvergadering gevolg deur 'n suksesvolle braai. In Februarie het die Tak 'n simposium oor sportbeserings deur Dr. Sperryn bygewoon. Gedurende Mei sou die nuwe President, Prof. Pistorius, die Tak toespreek oor huisartskunde. Die Tak beplan 'n Maitlandkursus in Julie deur Mej. Runnalls. Verder is twee Komiteevergaderings gehou.

Die Tak was diep geskok met die afsterwe van 'n jarelange lid, Mev. Ann Beyers, wat 'n baie aktiewe lid van die Vereniging was vanaf Mei 1959. Twee lede, $R$. van Blerk en J. Vorster, is na ander Takke verplaas. Die Voorsitster beplan om besoeke aan al die hospitale in Bloemfontein te bring om fisioterapeute aan te spoor om by die Tak aan te sluit.

\section{Southern Transvaal (Read by Miss B. Weakley)}

The Branch membership is now over 400 and attendance at monthly lectures has been good. Mr. Rabinowitch, a surgeon at Baragwanath Hospital, gave a very interesting and informative lecture on stab wounds of the chest in October. In November Miss Marion Heap, a stomatherapist, spoke to a small audience on her work in helping patients deal with colostomies and similar problems. In January the lecture venue was moved to the new Johannesburg Hospital, where Prof. Wagstaff, Professor of Community Medicine at Wits, gave a fascinating and informal talk on health care in the community. She gave the Branch an insight into the problems and successes met with in setting up the Soweto Primary Health Care Clinic. A symposium held in February proved to be very popular. Mr. Nainkin, an orthopaedic surgeon who runs the spinal clinic at the Johannesburg Hospital, and Mr. Lieberthal, a bracemaker, spoke on scoliosis, whilst Connie Siemers, the physiotherapist of the Unit, aided by two well-trained/ young patients, demonstrated the exercises used in treatment of the condition. In March the Branch was privileged to have Dr. Ruth Purtilo, an American physiotherapist, currently working in Sweden, speak to them on the expanding rôle of the physiotherapist from her American and Swedish experience. She also ran a workshop/symposium on the role of the physiotherapist in the community and patient/therapist relationship.

The Branch wishes to welcome Sue Keyes and Helen Isaacs back to the Branch after some time away overseas, and wish Jeanette Mitchell success in her year in the U.K. All new members are welcomed to the Branch.

\section{Western Province (Read by Miss S. Wessels)}

Five Branch General Meetings have been held and the following lectures were offered: P.U.V.A. by Dr. C. Kaiser of Groote Schuur Hospital; the physiology of exercise, by Dr. Tim Noakes from the University of Cape Town; industrial physiotherapy in England, by Mrs. B. Jaholkowski; and the co-operative patient coerced, compliant or collaborator? by Dr. Ruth Purtilo from the U.S.A.

A workshop on the treatment of rheumatoid arthritis was held jointly by physiotherapists and occupational therapists, and physiotherapists also attended a work-/ shop on burns organised by the occupational therapists. A workshop on after-care ethics under the leadership of Dr. Ruth Purtilo was organised by the University of Cape Town.

Miss M. J. Runnals read a paper on early referral for physiotherapy at the second General Practice Congress in Cape Town and on industrial physiotherapy at the Post-Graduate Industrial Medicine Course at the University of Stellenbosch. Mrs. E. Wakefield also read a paper on transport of paraplegics and quadruplegics at the latter course. Miss $R$. Lewis read a paper on chest physiotherapy at the U.C.T. 150 Academic Festival.

A sincere welcome is extended to all new members and especially to Pat Bowerbank, a member of the N.E.C. who has undertaken to organise a Branch of the Hospital group in the Western Cape.

\section{SPECIAL INTEREST GROUPS}

\section{Lecturers' Group (Read by Mrs. J. C. Beenhakker)}

The last six months have been devoted largely to implementing or completing projects already inaugura- 
ted. A meeting held on 2 May 1980 was followed by a workshop on educational programmes for new members of staff.

Revised minimal standards of degree courses have been submitted by the N.E.C. to the Professional Board, who have referred them to the different Universities for comment. A revised minimal Diploma syllabus has also been submitted. In response to a request from the Registration Committee this will be compared with the C.S.P. syllabus in order to try to establish a minimal standard for registration of overseas qualified physiotherapists.

Educational objectives for courses in physiotherapy education were formulated by Miss Gordon of the University of Cape Town, who will also correlate suggestions received from the different universities. Although several of the universities offer specific diplomas in physiotherapy education, the trend seems to be moving away from these diplomas in the direction of diplomas in tertiary education offered by the Education Faculties of many of the universities.

At present between them the Training Centres offer 15 additional registrable qualifications. Survey forms on priorities in continuing phyiotherapy education will be distributed in the near future. Clinical trials at both undergraduate and staff levels, are being conducted at five of the seven training centres.

Arising from an idea initiated by the University of the Orange Free State, a quarterly newsletter has been instituted. This newsletter will be produced by each university in rotation. The University of the Witwatersrand set the ball rolling, followed by the University of the Orange Free State. Both universities are to be congraulated on their work in the field of physiotherapy education.

The Annual General Meeting of the Group will be held during the Congress week in 1981, and the Group hopes to provide several speakers at the Congress itself.

The workshop on educational programmes for new members of training institutions was organised by the University of the Witwatersrand and was a great success. It covered principles of staff development; the areas of teacher competence; the objectives; short, mediunı and long-term planning and the establishment of control systems. A comprehensive list of references and some interesting information on rôle play was provided.

\section{Manipulative Therapists Group (Read by Mrs. J. Edeling)}

To date 88 physiotherapists have attended the 75-hour courses on spinal and peripheral manipulation sponsored by the Group and the Universities of Stellenbosch and the Witwatersrand. A further 52 physiotherapists are attending the courses which are currently being held at these two centres this year. The Group plans to have a guest lecturer from Australia to conduct a course on peripheral manipulation during 1981 or 1982 .

Miss Runnalls represented this country at the General Meeting of I.F.O.M.T., which was held in Christchurch, New Zealand, in February this year. South Africa is an Associate Member of this Group but hopes to attain Membership status by the end of 1980 . Mrs. J. Edeling read a paper on "Cervical headaches - diagnosis by manipulation" during this meeting.

The Transvaal Branch of the M.T.G. has formed a committee and it is hoped that they will become an official branch at the next Annual General Meeting, which will be held on May 26th 1980 at the University of Stellenbosch.

National Hospital Group (Read by Mrs. C. Bennetts)

Membership is 130 . The highlight of the period being reported on, has been a course on management for profits and efficiency in physiotherapy by Prof. Sandra van der Merwe. A future course on hospital administration and marketing of physiotherapy is being planned.

Four meetings of the Transvaal section have been held and the subjects discussed were: Physiotherapy in nutritional disorders; training and employment of blind physiotherapists; hand injuries with special reference to tendon repairs, and T.E.N.S. in the treatment of acute and chronic pain.

Two workshops on cardiac rehabilitation and the shoulder joint were also held.

A memorandum, on the training of departmental aides, which had been compiled from all the material previously submitted, was tabled. The objectives of this training would be as follows:

1. To free qualified physiotherapists from unskilled, semi-skilled and routine tasks and provide adequate services where chronic shortages exist.

2. To provide a limited service in rural areas where no services exist.

3. To improve the status and conditions of service as assistants.

Two plans were outlined, namely to set up training to provide aides for the same hospital and to provide aides for other hospitals. Long discussion followed and recommendations were made as to the creation of posts, minimal educational requirements for such training, and the control of departmental aides. It was thought that this could form part of the job description of a visiting or district physiotherapist. The objectives as outlined were agreed to, with reservations on objective 2 covering the limited service in rural areas. There was strong feeling that rural aides should be supervised. The meeting agreed to the principle of training departmental aides. The Lecturer's' Group offered assistance in compiling a suitable syllabus which would be submitted to the next meeting of the N.E.C. Once this has been finalized, a revised memorandum would be submitted to the Professional Board.

\section{Obstetric Association (Read by Mrs. M. Pretorius)}

Committee meetings were held at six-weekly intervals. There were no further developments to report on a post-graduate course in obstetric physiotherapy as the Committee was awaiting guidance from the Society. A reading list on ante- and post-natal training has been compiled and this is forwarded to midwives who seek advice on starting classes. Newsletters are sent out to members at two-monthly intervals. The postal library service which was started in the second half of last year, is functioning well. The most recent lecture on hypnosis in pregnancy and labour was held in Johannesburg and was very well attended. Permission has been obtained from the N.E.C. to place advertisements, encouraging mothers to attend obstetric physiotherapy training, in lay publications. The Committee is at present negotiating this with an advertising agent. A new register of practicing obstetric physiotherapists will be distributed to all registered gynaecologists in the R.S.A. and to the Branches and Sub-groups or Associations of the Society. A mobilisation course was held over 3 week-ends during April and May in Johannesburg. 
Miss Irwin-Carruthers explained that one would need the aims and objectives first of any post-graduate course which needs to be arranged and then one could work on the required syllabus.

Private Practitioners' Association (Read by Mr. Weil)

Many matters dealt with by the Society and Professional Board pertained to private practice. Events leading up to the present stage of the formation of the Tariffs Committee to investigate and determine the statutory medical aid fees, were outlined. Other matters dealt with were the amendment of article 16 of the Income Tax Act to include physiotherapists, increased group insurance, introductory circulars, prescribed areas, the formation of companies and the Workmen's Compensation Act, in relation to more than 20 treatments per injury.

Concern was expressed at the many pointers since the Health Act was promulgated in 1977, towards nationalisation of health services and socialised medicine. Some of these are: the acceptance by Provincial Hospitals of medical aid patients; the acceptance by the workman's rehabilitation centres in Johannesburg and Durban of private patients; private employing authorities and industry; the payment of W.C.A. fees to doctors and their employees who render physiotherapy treatment; the move of the S.A. Medical Association towards the alteration of regulations in order to enable a doctor in private practice to set up a health clinic owned by himself, and employ physiotherapists on a salary basis, instead of working more closely with private physiotherapists who render this service in rural and urban areas.

\section{REPORTS ON MATTERS ARISING FROM S.A.S.P. REPRESENTATIVES ON NATIONAL ORGANISA- TIONS}

National Council for the Care of Cripples (Read for Mrs. Matthias by Miss Blake).

The Council holds its annual general meeting combined with a two-day Congress in a different city each year. The Cerebral Palsy Division of the Council does the same on different dates. As representative of the S.A.S.P. and being on the Executive Committee of both bodies. Mrs. Matthias has submitted a report on the activities of the Society and has been given the opportunity to speak. In the past Mrs. Matthias has spoken herself or local physiotherapists have highlighted an aspect of physiotherapy either as an audio-visual or clinical presentation with patients. This has done a great deal to promote understanding of, and support for, physiotherapy among the representatives from government, provincial and local authorities concerned with rehabilitation who attended such meetings, as well as those from other welfare bodies. From 1959 to date the National Council for the Care of Cripples has given nearly R14000 for physiotherapy training both at undergraduate and postgraduate level.

The next meeting of this Council will be held in Pretoria in August 1980, and the Northern Transvaal has been invited to represent the Society at this meeting.

South African National Council for the Aged (Read by Mrs. Beenhakker)

At the Executive Committee meeting held in October 1979 , the problem of the shortage of occupational and physiotherapists was discussed. It was thought that this may be due to their relatively low salary scales and it was suggested that the Council should approach the Public Service Commission with a request that salary scales be brought into line with other professions such as social workers. A two-week course in geriatric care for registered nurses attached to old age homes, local authorities, Provincial Administration and others, has been introduced by the Department of Health. These courses will be offered in Johannesburg, Bloemfontein, Durban, Bellville, Pietersburg, Port Elizabeth, Kempton Park, East London and Pietermaritzburg. Physiotherapy will be covered in these courses and Mrs. Beenhakker would be interested to hear from physiotherapists who have been approached to give these talks.

S.A. Sports Association for Physically Disabled (Read by Miss Irwin-Carruthers)

A Springbok team will definitely be present at the International Parolympics to be held in Holland from 21 June to 5 July 1980 . Their participation in the games depends on a meeting of the Council of State, a nonpolitical body in the Dutch Parliamentary system, which is to be held in the middle of May. The games will be held in Arnhem and travel and accommodation have been finalized.

\section{ANY OTHER BUSINESS}

\section{Addresses of members}

Mrs. Beenhakker appealed to Branches to keep the General Secretary informed of all changes of addresses of their members. A recent survey had shown that addresses were not up-to-date despite all efforts of the Secretariat to keep it accurate.

\section{Appointment of a Business Consultant}

The Western Province Branch suggested that the services of a business consultant be used to draw up memoranda submitted, for instance, to motivate the improvement of salary scales to the Public Service Commission. This matter was referred back to N.E.C.

\section{Evaluation of the Profession}

It was also suggested that a job evaluation be done to determine how physiotherapy rates in terms of, or compared to, other professions. It was felt that this might be more comparative and may assist the representations to have physiotherapy classified as a profession.

\section{Congratulations}

It was recommended that N.E.C. send congratulations to $\mathrm{Mr}$. Jack Stockton on his retirement in Dublin and to Theunis Stoffberg on becoming a rugby Springbok.

\section{Date and Venue of Next Meeting}

The next meeting will be held on 18th October 1980 at the Johannesburg Hospital at 9.00 a.m. 